\title{
What Drives the Development of Social Inequality Over the Life Course? The German TwinLife Study
}

\author{
Elisabeth Hahn, ${ }^{1}$ Juliana Gottschling, ${ }^{1}$ Wiebke Bleidorn, ${ }^{2}$ Christian Kandler, ${ }^{3}$ Marion Spengler, ${ }^{4}$ \\ Anna E. Kornadt, ${ }^{3}$ Wiebke Schulz, ${ }^{3}$ Reinhardt Schunck, ${ }^{3,+}$ Tina Baier, ${ }^{3}$ Kristina Krell, ${ }^{3}$ Volker Lang, ${ }^{3}$ \\ Franziska Lenau, ${ }^{1}$ Anna-Lena Peters, ${ }^{3}$ Martin Diewald, ${ }^{3}$ Rainer Riemann, ${ }^{3}$ and Frank M. Spinath ${ }^{1}$ \\ ${ }^{1}$ Saarland University, Saarbruecken, Germany \\ ${ }^{2}$ University of California Davis, Davis, United States \\ ${ }^{3}$ Bielefeld University, Bielefeld, Germany \\ ${ }^{4}$ University of Tuebingen, Tuebingen, Germany \\ ${ }^{+}$now located at GESIS - Leibniz-Institut for Social Science, Koeln, Germany
}

\begin{abstract}
The German twin family study 'TwinLife' was designed to enhance our understanding of the development of social inequalities over the life course. The interdisciplinary project investigates mechanisms of social inequalities across the lifespan by taking into account psychological as well as social mechanisms, and their genetic origin as well as the interaction and covariation between these factors. Main characteristics of the study are: (1) a multidimensional perspective on social inequalities, (2) the assessment of developmental trajectories in childhood, adolescence, and young adulthood in a longitudinal design by using (3) a combination of a multi-cohort cross-sequential and an extended twin family design, while (4) capturing a large variation of behavioral and environmental factors in a representative sample of about 4,000 German twin families. In the present article, we first introduce the theoretical and empirical background of the TwinLife study, and second, describe the design, content, and implementation of TwinLife. Since the data will be made available as scientific use file, we also illustrate research possibilities provided by this project to the scientific community.
\end{abstract}

Keywords: social inequality, life chances, social stratification, behavior genetics, twin studies

Social inequalities are ubiquitous in societies. People are unequal in every conceivable way and in endless circumstances, immediate as well as enduring, with respect to both objective criteria and subjective experiences. But what counts as social inequality? To date, there is no common understanding how the term social inequality can be defined. Although economic inequalities are relatively objective and therefore easier to identify, social inequalities encompass more than monetary resources. Individuals differ, for instance, in their access to voting rights, their freedom of speech and assembly, the extent of property rights, their access to education and their success in school and labor market, their health care, quality of housing, traveling, access to credit, occupational outlook and attainment, other social goods and services, and in their chances to achieve their individual goals. Thus, Kerbo (2011) recently proposed a definition of social inequality as 'the condition where people have unequal access to valued resources, services, and positions in the society' (p. 11). In light of this definition, it becomes clear that we are confronted with inequalities that are mutually intertwined with the relative position of indi- viduals in a given society, that is, social stratification: power, class, status, money, and lifestyle.

Social stratification then refers to inequality insofar as it is not merely a matter of individual fortune, but rather inherent in prevailing forms of social relationships (Goldthorpe, 2010) or inequality of opportunities (e.g., Shavit \& Blossfeld, 1993). The positions that individuals hold within social stratification are considered to be major determinants of their life-chances. In addition, the experience of inequality is not just objective, but also subjective and relational because it involves comparisons to others; for example, in terms of income, education levels, health outcomes, or social and political participation. People establish their own social position by comparing themselves to

RECEIVED 8 March 2016; ACCEPTED 15 August 2016. First published online 17 October 2016.

ADDRESS FOR CORRESPONDENCE: Elisabeth Hahn, Department of Psychology, Saarland University, Campus A1 3, Saarbruecken D-66123, Germany. E-mail: e.hahn@mx.uni-saarland.de. 
others, for example, to their neighbors, their friends, their gender, or former generations such as parents and grandparents (Runciman, 1972; Warwick-Booth, 2013). This could have an influence on how people subjectively perceive and understand social trajectories. In sum, social inequalities can be described in terms of individual differences in a variety of indicators and outcomes and can be recognized by an individual or group via comparison to others objectively and subjectively.

In the following, social inequality is defined as a generic term for a set of indicators that characterize the relative standing of individuals with respect to their capacity to consume or produce goods that are either generally valued in our society or by the individuals themselves. Within this approach, one might distinguish among different categories of valued assets and resources. In the recent inequality literature, as well as in political task forces and committees (e.g., Alkire, 2005; Cunha \& Heckman, 2009; Fowler \& Schreiber, 2008; Giovannini et al., 2011; Lareau, 2002), several dimensions are discussed that should be assessed collectively when studying mechanisms of social inequalities. These dimensions not only include, for instance, skill formation and educational attainment, but also integration and participation in social and political life, as well as subjective perceptions of quality of life. People 'scoring high' on indicator variables related to these dimensions would be considered as relatively successful. In contrast, since failures and behaviors that are considered to go beyond the normal range are also indicators of social inequalities, the investigation of deviant behavior and behavioral problems provides further insight into this complex phenomenon.

In such a comprehensive framework, it is important to note that the considered indicators are not only valuable goods in their own right. Rather, most of them can also serve as functional resources that individuals can invest to achieve other desired goods in the future. For example, educational attainment can be seen as an investment into labor market outcomes later in life but can also be considered as a valuable goal itself. Another aspect of this approach addresses the individual experience of inequalities. Negative life events, such as, for instance, unemployment, can have long-lasting deleterious effects on subjective wellbeing (Headey, 2010) given that losing one's job can be humiliating and extremely harmful to the health and social prestige of those affected. Apart from individual differences in the probability of experiencing the event of unemployment, there is also substantial variation across individuals in their reactivity to job loss, a fact that is not yet well understood (Bonanno, 2004; Lucas, 2007). Hahn et al. (2015) provided first evidence that certain personality traits act as risk factors for individuals faced with a brief period of unemployment. Moreover, national inequality indices (e.g., income inequality and unemployment rate) have been shown to be negatively associated with wellbeing, a fact that could be explained by social relations such as status anxiety, social comparison, or economic worries (Oishi et al., 2011; Roth et al., 2016; Welsch, 2007). It can also be expected that all these mechanisms influencing subjective quality of life are in part associated with genetic differences between individuals (Turkheimer, 2000). Therefore, a special focus should lie on possible interactions between personal characteristics and different situations across the life course by taking genetic confounds into account when the goal is to understand economic behavior and psychological wellbeing. Here, individual experiences are not only a result, but can also be a potential ingredient for the explanation of inequalities and can serve as strong motivating forces at all levels.

To explain mechanisms of social inequalities across the life span, several research disciplines have developed multiple approaches to investigate different aspects along the development and persistence of social inequalities by using corresponding methods. However, the majority of research in this field was limited in its ability to incorporate both multiple individual and social characteristics, as well as information on genetic influences to identify processes of social developments systematically.

\section{Sociological Approaches to Social Inequality}

A central goal of sociological research is to identify determinants of individual life courses and opportunities within and between populations. One of the major questions in sociological research addresses how society shapes the life course of its members. However, a theoretical problem arises, since the defined starting point in many approaches - that is, the individual - is already socially formed in terms of race, gender, and the family of origin to which the individual belongs. Thus, lifetime analyses, social stratification, and social mobility research tend to study associations between social origins, such as social class, socio-economic status (SES) or parental resources, and social outcomes of the individual - again, social class, welfare state, or career success (Erikson \& Goldthorpe, 1992). Research can, by and large, be characterized by following differential pathways to success and failure over the life course while searching for specific characteristics within and outside the parental home that provide a child with good or bad chances in life.

For instance, the status-attainment approach (for an overview, see Grusky et al., 2008) has become one of the most widely used theoretical perspectives in sociological research on social inequality and economic well-being. The basic status-attainment model comprises three paths: (1) the direct impact of social origin on occupational status, (2) the direct impact of social origin on education, and (3) the direct impact of education on occupational status, with (2) and (3) measuring the indirect effect of social origin on occupational status (see Figure 1). Studies in the tradition of this approach and other sociological research methods have typically investigated the extent to which the present 


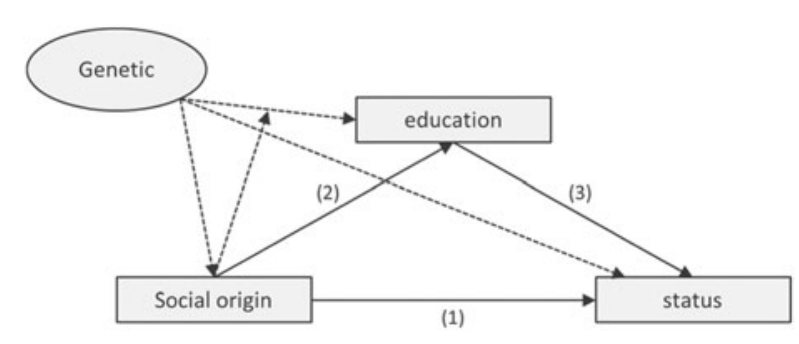

FIGURE 1

Modified status attainment model.

occupational status of an individual can be explained by the occupational status of the family in which the person grew up, and in more recent studies, also considering the person's own educational attainment. Among the most robust findings of this research tradition are: (1) that social origins play an important role for educational and status attainment even though this effect tends to be less strong and varies across societies, (2) that effects are stronger at earlier than at later educational transitions, and (3) that education mediates a substantial part but not the full association between origins and destinations (Breen \& Jonsson, 2005; Breen et al., 2009; Jackson et al., 2005).

One criticism of the status attainment approach is that even if all paths in the model were accurately specified, it remains unclear how, for example, social origins influence occupational status. Moreover, this model cannot explain if and why responses to societal influences are not homogenous, or at least contingent, among all individuals. In other words, the assumption of uniform causal effects is misleading (e.g., Abbott, 2001). Over the years, traditional research models have been extended in a number of ways, first and foremost by the Wisconsin model, which integrates interpersonal influences and aspirations as mediating mechanisms (e.g., Hauser et al., 2000; Heckman 2006).

Also, much classical psychological constructs such as the Big Five personality traits (Costa \& McCrae, 1992) or aspects of self-concept and motivation have been included, showing strong associations to educational and academic achievement. There is growing evidence that noncognitive skills, such as self-control and self-efficacy, may be as important as cognitive skills (Heckman \& Kautz, 2012; Richardson et al., 2012). Within the Five Factor model of personality, academic performance is most consistently associated with conscientiousness (Poropat, 2009), which is highly correlated with grit (Duckworth \& Quinn, 2009). Moreover, externalizing psychopathology has consistently been associated with academic difficulties (Breslau et al., 2008; Esch et al., 2014), as has poor emotion regulation (Ivcevic \& Brackett, 2014).

Nevertheless, even with relatively comprehensive measurements and an inclusion of psychological mechanisms, the overall impact of social origins and individual characteristics on individual success and failure is still not fully understood. This could be due to the fact that both individual as well as social factors may be biased by unmeasured confounds (Jencks \& Tach 2006; Smeeding et al., 2011). Modeling patterns of life-course events as well as social mobility by using the individual and its social background as starting point neglects that individuals already differ with respect to their genetic makeup from the very start and that they react differently to environmental conditions based on genetic disparity (Pinker, 2003; Polderman et al., 2015; Scarr, 1992, 1993; Visscher et al., 2012).

Genetic variation is obviously a major source of individual differences in various life outcomes, but also of differences in how individuals react to social conditions that, if unconsidered, lead not only to less complete but also to less precise explanations. The individual genetic makeup (i.e., genotype) exists prior to individual social influences and may affect social inequality due to genetic variation. However, the unfolding of the genotype depends on environmental opportunities (Scarr, 1992, 1993). Thus, both genetic and environmental sources shape people's rankings in the system of social inequalities. As a consequence, indicators of social origin are not the only starting point in life, as assumed in the status attainment model, but are rather part of the social structuring of life chances. In fact, it can be assumed that the measured impact of ascribed characteristics and positions, like the attributes of the family of origin are, to a certain degree, influenced by genetic factors (as illustrated in Figure 1). This involves considering that supposed environmental contributions are in part active via genetic factors and consequently genetic and social inheritance should be distinguished.

\section{Quantitative Behavioral Genetics}

Decades of behavioral genetic research have shown that the vast majority of individual-level variables are influenced by both genetic as well as environmental factors (for a review, see Polderman et al., 2015; Turkheimer, 2000). The fact that genetic influences play a crucial role in explaining individual differences does not only apply to 'proximal' characteristics and behavioral outcomes like health and personality, but also includes more 'distal' ones, such as education, demographic events, and social inequalities (e.g., Guo \& Stearns, 2002; Turkheimer, 2000). Moreover, it is logical and at the same time empirically proven that whole genome effects do not necessarily become smaller as we move from psychological traits to actions and outcomes (Freese, 2008). In behavioral genetic research, the question of 'how much' of the variance genetic versus environmental factors explain has already been replaced by studies of the processes that mediate the relation between the genome and the social phenomenon of interest. However, existing behavioral genetic studies suffer from not making full use of the sociological life-course perspective and from not having enough cases to follow the complicated patterns of 
genome-environment interactions. Moreover, most studies do not consider specific social factors over time to explain broader social phenomena and are often either restricted to certain topics (mostly concentrating on health or behavioral disorders), or to a specific age range.

To overcome these shortcomings of previous research attempts and to rigorously study sources of social inequalities with respect to genetic and environmental influences, at least three important issues should be noted.

First, the effect of genes could depend on the environment and/or the effect of the environment could depend on the genotype (Plomin et al., 2008). Such patterns are designated as gene-environment interactions $(\mathrm{G} \times \mathrm{E})$, that is, the moderation of genetic predispositions by environmental experiences or, in other words, the genetic sensitivity to environmental influences. However, simple quantitative genetic models average heritability estimations over any group differences (e.g., differing SES) within a population, although this is not an adequate approach in the light of the growing evidence for $\mathrm{G} \times \mathrm{E}$. In order to disentangle these complex patterns of the gene-environment interplay, the following aspects have to be taken into account to transform a mere statistical association between genome and outcome into an explanation based on a chain of interlinking causal factors (e.g., Freese, 2008; Kendler, 2001; Rutter et al., 2001; Shanahan et al., 2003): (1) biological and/or psychological processes have to be measured appropriately to elucidate the path from the genome to behavioral outcomes. Given that social influences at the level of individual attributes alone are confounded by influences of the social environment and individual reactions to them, various levels of contextual influences need to be measured. (2) To understand how social situations and circumstances influence genetic expression requires examining biographical developments and the accumulation of life experiences. (3) Heritability estimates of outcomes do not only characterize a population (or sample) of individuals but also constitute properties of social systems that reflect the extent to which genetic variation in that system influences individual outcomes.

Second, behavioral genetic studies of social inequalities need to address and evaluate the question whether estimates of environmental influence derived from genetically informative samples apply to the general population (Rutter et al., 2001). According to Farber (1981), it is disputable whether any sample of twins can actually be representative for the population, because of inherent factors of the twin existence, such as a different family structure or the shared prenatal environment. Although twinversus-singleton comparisons have not yielded differences in the prevalence rates regarding characteristics of antisocial behavior or antisocial personality traits (Gjone \& Nøvik, 1995), it remains an open question whether this also applies for other psychological and sociological factors and mechanisms. To increase the generalizability of the results, a stringent behavioral genetic study of social inequalities needs to ensure that the twin (family) sample under study is representative for the population of interest.

Third, to identify specific environmental effects on social inequalities, a broad sampling of measured 'environmental' variables is required that allows the aggregation of measures to test for interactions among environmental variables, and to study stability and change of environmental factors over time. Since environmental effects include more than just environment shared or non-shared by twins, research designs that comprise not only twins but also significant interaction partners (parents, non-twin siblings, and partners) as target individuals (and not only as raters providing information about twins) are especially promising, because it provides a wealth of measures of the social environment. Moreover, to study environmental effects, geneenvironment correlations ( $\mathrm{rGE}$ ), and $\mathrm{G} \times \mathrm{E}$, the full variation of any given environmental factor should be covered.

\section{Integrating Sociological Approaches and Quantitative Behavioral Genetics}

To explain the development of social inequalities over the life course, it is crucial to understand how genetic heterogeneity is attended to 'by society' and translated into advantages or disadvantages in the first place, and when and under which circumstances the expression of biological dispositions may be enhanced or restricted by environmental influences. To test whether a putative environmental variable really affects behavior environmentally, designs that are able to control for genetic influences are indispensable.

Over the last years, studies have increasingly focused on the interplay between genes and the environment. This development has been driven by the rapid advances in molecular genetics as well as the methodological advances that facilitate the possibility to analyze moderation using twin designs (Caspi et al., 2002; Plomin \& Crabbe, 2000; Purcell, 2002). These advances have led to a growing number of genetically informed studies that have included measures of environmental factors to their designs. The coupling of well measured environment and a genetically informed design can provide a good starting point to advance our understanding of gene-environment interplay.

For example, Conley et al. (2015) investigated the relation between parental and offspring education. To understand whether the estimated social influence of parental education on offspring education is biased or moderated by genetic inheritance, they used findings from a recent, large genome-wide association study on educational attainment to derive an individual genetic score to predict educational attainment. Using data from two independent samples, this genetic score significantly predicted years of schooling in both between-family and within-family analyses. Furthermore, the phenotypic parent-child correlations in education could be split into one-sixth genetic transmission and 
five-sixths social inheritance. Conditional on the child's genetic score, the parental genetic score had no significant relationship to the child's educational attainment. Finally, measured socio-demographic variables at the parental level moderated the effects of offspring's genotype, providing evidence for the importance and interplay of both genetic and social inheritance.

Also, a number of quantitative $\mathrm{G} \times \mathrm{E}$ interaction studies investigated the effect of the family environment on the heritability of intelligence (Rowe et al., 1999; Scarr-Salapatek, 1971; Tucker-Drob \& Bates, 2016; Tucker-Drob et al., 2011; Turkheimer et al., 2003). The results of these studies suggested that parental education and other socio-economic indicators of the family can modify the relative contribution of genetic and environmental effects on individual differences in intelligence. In U.S. samples, for example, genetic effects on intelligence were stronger in families with higher SES compared to lower SES families. In other words, environmental factors influencing intelligence were more important at the lower end of the SES distribution. In sum, Tucker-Drob and Bates (2016) found that the magnitude to which these factors of the family environment moderate genetic and environmental influences on intelligence differs across nations, indicating 'that Gene $\times$ SES effects are not uniform but can rather take positive, zero, and even negative values depending on factors that differ at the national level' (p. 10). Also, many studies have begun to summarize effects of $\mathrm{G} \times \mathrm{E}$ across multiple studies systematically and quantitatively regarding a variety of phenotypes. For example, Byrd and Manuck (2014) showed in a meta-analysis that MAOA variation (i.e., variation in the gene encoding monoamine oxidase-A) moderates effects of early life adversity (e.g., physical and sexual abuse, harsh discipline, neglect, or assault) on male subjects' aggressive and anti-social behaviors.

To further integrate sociological and behavior genetic research approaches and to overcome the aforementioned shortcomings of existing studies, the German twin family study 'TwinLife' was launched in 2013 to examine various mechanisms of genetic and environmental factors involved in the development of social inequalities. By means of the TwinLife study, more specific research questions such as 'What are the shaping environmental resources enhancing genetic potential for behavioral characteristics related to success in school?' or 'To what extent do early institutional environmental circumstances influence the life course in dependence of our genetic makeup?' can be investigated.

\section{The TwinLife Study}

TwinLife is an interdisciplinary project that combines the perspectives of psychological and sociological theories and research with behavioral genetic methodology. The goal of TwinLife is to examine the interplay between genetic and environmental mechanisms that shape, promote, and inhibit social inequalities over the life course. TwinLife integrates the know-how of these different research disciplines to investigate the development of social inequalities by taking into account psychological as well as social mechanisms, their genetic origin, and the interaction and covariation between 429 these factors. Therefore, a quantitative behavioral genetic research design was applied to assess the relative contributions of genetic and environmental factors in observable phenotypic variation by comparing the phenotypic similarity in relatives with known (and different) average degrees of genetic relatedness. One of the major goals of TwinLife is to study how and at which environmental state genes and environments shape individual life courses, and to identify covariation and interaction of genetic and environmental sources in a longitudinal design. Furthermore, by measuring familial and individual environmental factors, it becomes feasible to identify specific environmental characteristics within and between families that may explain causes of social inequalities. Using genetically informative data allows us to control statistically for genetic influences to identify 'true' environmental factors that exert a direct effect on success and failure in life. On the other hand, TwinLife can be leveraged to understand under which circumstances 'environmental' constructs are influenced by individuals via their genetically influenced characteristic. This approach may help to guide sociopolitical interventions such as strategies for remediating and family investment in sensitive periods (Cunha \& Heckman, 2009). Derived from the statements above, TwinLife was designed to address the following four key issues:

1. TwinLife adopts a multidimensional perspective on social inequalities, including inequalities in different major life domains. Therefore, social inequality is considered as a multi-dimensional construct comprising a variety of indicators that characterize the relative standing of individuals in our society. We explicitly distinguish between subjective and more objective dimensions of inequality (Stiglitz et al., 2010) and measure a broad range of psychological characteristics to capture the variety of individual heterogeneity for the interplay between individuals and society.

2. Twinlife investigates developmental trajectories across childhood, adolescence, and young adulthood in a longitudinal design. Through the implementation of a cross-sequential design, twins from four different age groups $(5,11,17$, and 23 years at the first measurement occasion) are examined repeatedly. Assessment begins shortly before school enrollment in the youngest group and ceases when most of the career-related decisions are completed in the oldest group.

3. Furthermore, the Extended Twin Family Design (ETFD) applied in TwinLife is conceptualized in accordance to the Nuclear Twin Family Design (NTFD; 
Heath et al., 1985), comprising first-degree relatives of same-sex monozygotic and dizygotic twins, but extended by the inclusion of step-family members as well as partners and spouses in case the twins having reached a certain age. This extension aims at providing a richer assessment of the environment in which the twins grow up and live including important social interactions.

4. Finally, TwinLife explicitly aims at capturing a large variation of behavior and environmental factors in a representative sample of twin families. The quantification of environmental effects - those shared within families as well as those not shared - is a central concern. Both the substantial number of participants realized in an ETFD and the representative variation of the environment make it feasible to overcome shortcomings in existing genetically informative studies and, in particular, to more adequately take genetic information into account to identify environmental factors that exert an effect on success and failure in life.

\section{Multidimensional Perspective on Social Inequalities}

The focus of TwinLife is on the development of social inequality over the life course, including genetic, social, and psychological factors shaping social inequalities within and between families. The set of measurements reflects this focus by assessing six broad categories of constructs: (1) skill formation and education, (2) career and labor market attainment, (3) social integration and participation, (4) subjective perception of quality of life, (5) physical and psychological health, as well as (6) deviant behavior and behavioral problems (see Figure 2).

The selection of these six inequality domains was based on their prominence in the inequality literature (e.g., Alkire, 2005; Cunha \& Heckman, 2009; Fowler \& Schreiber, 2008; Lareau, 2002) as well as on their potential meaning for mechanisms involved in the development of social inequalities. These domains are also featured in recent discussions and task forces on social inequality (e.g., Giovannini et al., 2011).

To cover a broad range of putative environmental influences, TwinLife comprises a large set of age- and domainspecific environmental measures as well as demographic measures and aspects of the twin situation. The complete survey program assessed within the first in-house interview of the first wave is presented in Table $1 .^{1}$ In some cases, respondents answer questions about both, themselves, and about other family members. In particular, parents report

\footnotetext{
1 Depending on the variables in question and the age of the participant, questions are presented either by the interviewer (computer-assisted personal interview, CAPI), as self-report on a computer screen (computer-assisted self-interview, CASI), or as paper-pencil questionnaires. All targets in our design not living in the household (i.e., biological parents, biological siblings, and partners of the twins) were tested with a reduced version of the questionnaire that was mailed to them.
}

on their own characteristics and also on their children's characteristics when the twins or siblings are too young to complete self-reports. For 328 participating twin pairs, we also collected DNA samples in order to validate the zygosity determination using physical similarity ratings in the three underaged cohorts (Becker et al., 1997; Oniszczenko et al., 1993; Price et al., 2000).

A wide array of psychological constructs was included in TwinLife to examine developmental paths in the aforementioned domains of social inequality. Thus, the possible contribution of, for instance, motivation, (non-)cognitive skills, and personality characteristics over the life course can be studied simultaneously with sociological constructs. Apart from this, TwinLife puts a special focus on environmental factors and developmental tasks that become relevant in different phases of personality and competency development over the life course (i.e., early childhood, adolescence, early and middle adulthood). In this respect, we did not only measure the occurrence of various life events, but also assessed how persons subjectively evaluate emerging tasks in school and job life, romantic relationships, family life, social life, and physical changes.

This research program was established by taking existing panel studies in Germany (e.g., Pairfam, SOEP, and NEPS) and beyond (e.g., TEDS and Add Health) into account to assess measures for selected explanatory and outcome factors with a potential for cross-study comparisons. More precisely, we used partly the same or similar operationalizations of core constructs to create the synergetic potential as well as the possibility for extended analyses with independent samples. Linking our research program to other largescale panel studies enhances the power for causal inference for several interdisciplinary research questions in the field of life chances.

\section{Cross-Sequential Design}

Longitudinal studies with a focus on the measurement of environmental characteristics are required to study social inequality as a life-course phenomenon. Moreover, the investigation of multiple cohorts over time (i.e., the crosssequential design) allows us to overcome shortcomings inherent in cross-sectional age group comparisons. Therefore, TwinLife follows the development of four cohorts of same-sex twins and their families.

For the first measurement occasion, families were invited to take part in the study when the twins were $5,11,17$, and 23 years old. Each of the four age cohorts was derived from birth cohorts spanning 2 years, ${ }^{2}$ resulting in about 1,000 twin families in each cohort (500 per birth year) and

2 Each cohort encompasses birth cohorts spanning 2 years due to the small number of expected twin births in Germany. Therefore, we organized data collection in a way that each twin pair within the same cohort will be examined at about the same age. For example, families with 5-year-old twins born in $2009(n=500)$ will be studied in 2014 and families with 5-year-old twins born in $2010(n=500)$ will be studied in 2015. 
TABLE 1

Summary of Measures Included in TwinLife

\begin{tabular}{|c|c|c|c|c|}
\hline & Twins & Siblings & Parents & Twin-partner* \\
\hline \multicolumn{5}{|l|}{ 1. Skill Formation and Education } \\
\hline \multicolumn{5}{|l|}{ Educational success } \\
\hline School report (copy) & $x$ & $x$ & & \\
\hline \multicolumn{5}{|l|}{ Intelligence } \\
\hline $\begin{array}{l}\text { + Subtests (Matrices, Series and Classification) from Culture Fair Intelligence Test, } \\
\text { CFT 1-R }\end{array}$ & $x$ & $x$ & & \\
\hline $\begin{array}{l}\text { \#Subtests (Matrices, Series, Classification and Reasoning) from Culture Fair } \\
\text { Intelligence Test CFT 20-R2 }\end{array}$ & $x$ & $x$ & $x$ & \\
\hline Self-assessed intelligence & & & & $x$ \\
\hline \multicolumn{5}{|l|}{ Cognitive development } \\
\hline Information derived from 'U-Heft'3 & $x$ & $x$ & & \\
\hline $\begin{array}{l}\text { Tutoring and homework help, special educational treatment and attendance of } \\
\text { special school, following NEPS }\end{array}$ & $x$ & $x$ & & \\
\hline Competence ratings, following NEPS ${ }^{A}$ and BBK $3-6^{4}$ & $x$ & $x$ & & \\
\hline Media use, following NEPS ${ }^{A}$ & $x$ & $x$ & $x$ & $x$ \\
\hline \multicolumn{5}{|l|}{ Academic self-concept } \\
\hline${ }^{+}$Scales from the Self-Description Questionnaire for Preschoolers (SDQP) ${ }^{5}$ & $x$ & $x$ & & \\
\hline Scales to measure academic self-concept (SESSKO) ${ }^{6}$ & $x$ & $x$ & $x$ & $x$ \\
\hline \multicolumn{5}{|l|}{ Motivation } \\
\hline${ }^{\# P e r c e i v e d ~ c o m p e t e n c e, ~ I n t r i n s i c ~ M o t i v a t i o n ~ I n v e n t o r y ~(I M I) ~}{ }^{7}$ & $x$ & $x$ & $x$ & $x$ \\
\hline Learning motivation scales to measure subjective school values (SESSW) ${ }^{8}$ & $x$ & $x$ & $x$ & \\
\hline $\begin{array}{l}\text { Achievement motivation scales to measure learning and performance motivation, } \\
\text { version for students (SELLMO-S) }{ }^{9} \text {, adapted for adults }\end{array}$ & $x$ & $\mathrm{x}$ & $\mathrm{x}$ & $\mathrm{x}$ \\
\hline Learning goals items developed for TwinLife & $x$ & $x$ & $x$ & $x$ \\
\hline \multicolumn{5}{|l|}{ Personality } \\
\hline + Big Five Dimensions, Big Five Inventory for school children, following SOEPB & $x$ & $x$ & & \\
\hline${ }^{\# B i g}$ Five Dimensions, Big Five Inventory (BFI-S), following SOEP10 & $x$ & $x$ & $x$ & $x$ \\
\hline Self-efficacy, General Self-Efficacy Short Scale (ASKU) ${ }^{11}$ & $x$ & $x$ & $\mathrm{x}$ & $x$ \\
\hline \multicolumn{5}{|l|}{ Self-esteem } \\
\hline${ }^{+}$Single-Item Self-Esteem Scale ${ }^{12}$ & $x$ & $x$ & & \\
\hline${ }^{\#}$ Rosenberg Self-Esteem Scale (RSE) ${ }^{13}$ & $x$ & $x$ & $x$ & $x$ \\
\hline \multicolumn{5}{|l|}{ 2. Career and labor market attainment } \\
\hline Employment status, following SOEPB & $\mathrm{x}$ & $x$ & $\mathrm{x}$ & $\mathrm{x}$ \\
\hline Education and career plans, following SOEP ${ }^{B}$ & $x$ & $x$ & $x$ & $x$ \\
\hline Actual education and qualification, following SOEPB & $x$ & $x$ & $x$ & $x$ \\
\hline School career, following NEPS ${ }^{A}$ and SOEPB & $x$ & $x$ & $x$ & $x$ \\
\hline Perceived job security and satisfaction, following SOEPB and B3 Questionnaire ${ }^{14}$ & $x$ & $x$ & $x$ & $x$ \\
\hline Wages, income and welfare dependency, following SOEPB and B3 Questionnaire ${ }^{14}$ & $\mathrm{x}$ & $x$ & $x$ & $\mathrm{x}$ \\
\hline Economic preferences, following SOEPB & $\mathrm{x}$ & $\mathrm{x}$ & $\mathrm{x}$ & $x$ \\
\hline \multicolumn{5}{|l|}{ 3. Social integration and participation } \\
\hline Social participation, following AID-A DJI-Survey ${ }^{15}$ & $\mathrm{x}$ & $\mathrm{x}$ & $\mathrm{x}$ & $\mathrm{x}$ \\
\hline Experiences with discrimination, following SOEPB & $x$ & $x$ & $x$ & $x$ \\
\hline Political participation, following SOEPB & $x$ & $x$ & $x$ & $x$ \\
\hline Migration background, following SOEPB & $x$ & $x$ & $x$ & $x$ \\
\hline Citizenship, following SOEP ${ }^{B}$ & $x$ & $x$ & $x$ & $x$ \\
\hline Social networks, following SOEPB & $x$ & $\mathrm{x}$ & $x$ & $x$ \\
\hline \multicolumn{5}{|l|}{ 4. Subjective perceptions of quality of life } \\
\hline \multicolumn{5}{|l|}{ Global life satisfaction } \\
\hline${ }^{+}$Satisfaction with Life Scale for Children (SWLS-C ${ }^{16}$ ) & $x$ & $x$ & $x$ & $x$ \\
\hline${ }^{\#}$ Satisfaction with Life Scale (SWLS ${ }^{17}$ ) & $x$ & $x$ & $x$ & $x$ \\
\hline \multicolumn{5}{|l|}{ Domain satisfaction } \\
\hline $\begin{array}{l}\text { Satisfaction with health, work or school, income, leisure, family life, partnership, } \\
\text { acquaintances and circle of friends, following SOEPB }\end{array}$ & $x$ & $x$ & $x$ & \\
\hline Satisfaction with relationship to twin or twins items developed for TwinLife & $x$ & $x$ & & \\
\hline 5. Physical and psychological health & & & & \\
\hline Subjective health, Short Form-8 Health Survey (SF-8) ${ }^{18}$ & $x$ & $\mathrm{x}$ & $\mathrm{x}$ & $\mathrm{x}$ \\
\hline Objective health, following SOEPB & $x$ & $x$ & $x$ & $x$ \\
\hline Health behavior, following SOEPB & $x$ & $x$ & $x$ & $x$ \\
\hline Height and weight items developed for TwinLife & $x$ & $x$ & $\mathrm{x}$ & $x$ \\
\hline 6. Deviant behavior and behavioral prob & & & & \\
\hline Internalizing problems, following Strength and Difficulties Questionnaire (SDQ) ${ }^{19}$ & $\mathrm{x}$ & $\mathrm{x}$ & $\mathrm{x}$ & \\
\hline Externalizing problems, following Strength and Difficulties Questionnaire (SDQ) ${ }^{19}$ & $x$ & $x$ & $x$ & \\
\hline $\begin{array}{l}\text { Deviant and delinquent behavior, following Questionnaire Student Report }{ }^{20} \text { and } \\
\text { items developed for TwinLife }\end{array}$ & $x$ & $x$ & $x$ & $x$ \\
\hline Demographics & & & & \\
\hline Household Questionnaire, developed for TwinLife & & & & \\
\hline Persons in the household (Household grid), following SOEPB and Pairfam ${ }^{C}$ & $x$ & $x$ & $x$ & \\
\hline Home (house or flat, environment, ownership), following SOEPB & $x$ & $x$ & $x$ & \\
\hline Environment & & & & \\
\hline Parenting style, following Pairfam ${ }^{C}$ & & & & \\
\hline Subscales (Monitoring, Warmth, Rules, Negative Communication and Control) & $x$ & $x$ & $x$ & \\
\hline Activities with children, following Pairfam ${ }^{C}$ & $\mathrm{x}$ & $x$ & $x$ & \\
\hline
\end{tabular}


TABLE 1

(Continued)

\begin{tabular}{|c|c|c|c|c|}
\hline & Twins & Siblings & Parents & Twin-partner* \\
\hline \multicolumn{5}{|l|}{ Sibling relationship } \\
\hline Scales from Adult Sibling Relationship Questionnaire (ASRQ ${ }^{21}$ ) & $x$ & $x$ & & \\
\hline $\begin{array}{l}\text { Relationship to grandparents, following Pairfam }{ }^{C} \text { and items developed for } \\
\text { TwinLife }\end{array}$ & $x$ & $x$ & $x$ & \\
\hline Home environment, Chaos, Hubbub and Order Short Scale (CHAOS) ${ }^{23}$ & $x$ & $\mathrm{x}$ & $x$ & $x$ \\
\hline $\begin{array}{r}\text { Subscales (autonomy, structure, control, emotional support) } \\
\text { Zygosity and twin specific measures }\end{array}$ & $x$ & $x$ & & \\
\hline \multicolumn{5}{|l|}{ Zygosity } \\
\hline $\begin{array}{l}\text { +Parents' Reports Questionnaire, following } \operatorname{CoSMoS}^{\mathrm{D}} \\
\text { \# Self-report questionnaire }\end{array}$ & $\begin{array}{l}x \\
x\end{array}$ & & & \\
\hline Twin specific questions developed for TwinLife & & & & \\
\hline
\end{tabular}

Note: Constructs were sometimes measured over parent ratings, especially for younger children; *Partners outside the twins' household were assessed by using a short version of the questionnaire program, and partners living in the twins' household were assessed with the full questionnaire program; A = NEPS: National Educational Panel Study (Blossfeld et al., 2011); B = SOEP: Socio-Economic Panel (Wagner et al., 2007); C = Pairfam: Panel Analysis of Intimate Relationships and Family Dynamics (Huinink et al., 2011); D = CoSMoS: German Twin Study on Cognitive Ability, Self-Reported Motivation, and School Achievement (Hahn et al., 2013); ${ }^{+}$Instrument for young children; \#Instrument for adolescents and adults; ${ }^{1}$ CFT1-R: Culture Fair Test, Grundintelligenztestskala 1-Revision (Weiß \& Osterland, 2013); ${ }^{2}$ CFT20-R: Culture Fair Test, Grundintelligenztest Skala 2- Revision (Kuhn et al., 2008); ${ }^{3}$ The 'u-Heft' is an examination record, which documents the results of nine medical check-ups from birth to school-age; ${ }^{4}$ Interviewer rating, BBK 3-6: Beobachtungsbogen für 3- bis 6-jährige Kinder (Frey et al., 2008); ${ }^{5}$ SDQP: Self-Description Questionnaire for Preschoolers (Marsh et al., 2002); ${ }^{6}$ SESSKO: Skalen zur Erfassung des schulischen Selbstkonzepts (Dickhäuser et al., 2002); ${ }^{7}$ IMI: Intrinsic Motivation Inventory (McAuley et al., 1989); ${ }^{8}$ SESSW: Skala zur Erfassung subjektiver schulischer Werte (Steinmayr \& Spinath, 2010); ${ }^{9}$ SELLMO-S: Skalen zur Erfassung der Lern- und Leistungsmotivation - Version für SchülerInnen (Spinath et al., 2002); ${ }^{10}$ BFI-S: Big Fivelnventory, form S (Gerlitz \& Schupp, 2005); ${ }^{11}$ ASKU: Allgemeine Selbstwirksamkeit Kurzskala (Beierlein et al., 2012); Single-Item Self-Esteem Scale (Robins et al., 2001); ${ }^{13}$ RSE: Rosenberg Self-Esteem Scale (Rosenberg, 1965); ${ }^{14}$ B3 Questionnaire (Abendroth et al., 2014); ${ }^{15}$ AID:A - DJI-Survey: Aufwachsen in Deutschland Alltagswelten, Deutsches Jugendinstitut (2009); ${ }^{16}$ SWLS-C: Satisfaction with Life Scale adapted for Children (Gadermann et al., 2010); ${ }^{17}$ SWLS: Satisfaction with Life Scale (Diener et al., 1985); ${ }^{18}$ SF-8: Short Form-8 Health Survey (Ellert et al., 2005); ${ }^{19}$ SDQ: Strength and Difficulties Questionnaire (Goodman, 1997); ${ }^{20}$ Fragebogen Schülerbefragung Dortmund 2012: SFB Bielefeld (Reinecke et al., 2013); ${ }^{21}$ ASRQ: Adult Sibling Relationship Questionnaire (Heyeres, 2006); ${ }^{22}$ SRI: Sibling Relationship Inventory (Boer et al., 1997); ${ }^{23} \mathrm{CHAOS}$ Chaos, Hubbub and Order Short Scale, six-item version (Wang et al., 2012); ${ }^{24}$ Self-report questionnaire (Oniszczenko et al., 1993).

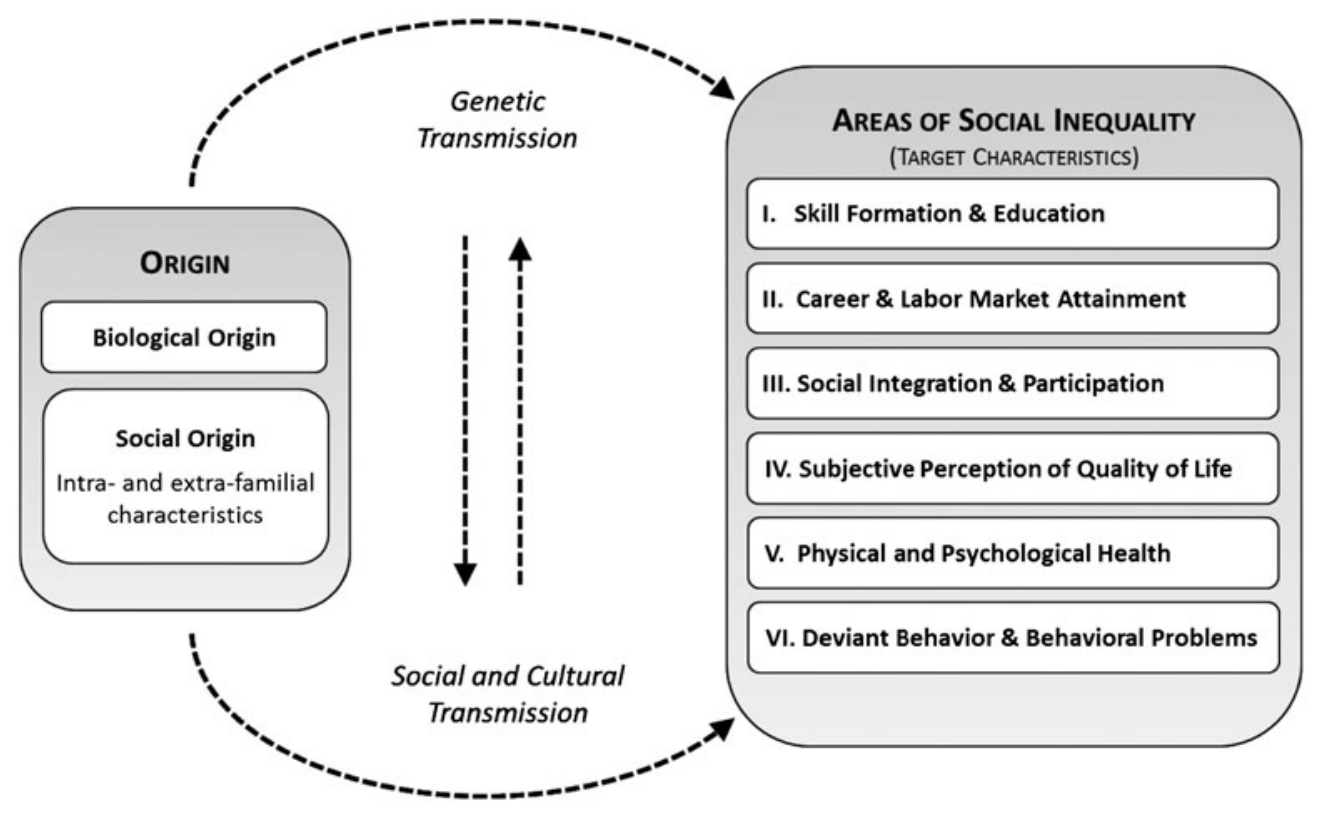

FIGURE 2

Main focus of TwinLife. 
a total of approximately 4,000 twin families when the first assessment will be completed. To assess each twin family within the same cohort at about the same age, each wave is organized into two half-waves, each half following the respective birth cohort of twins. The first wave of the TwinLife study comprises a more extensive face-to-face interview with all family members chosen in the participants' homes (see Table 1 for an overview of instruments) and a telephone interview. A shorter telephone interview takes place 1 year after the home interviews. Apart from followup questions on the current living situation, education and work situation, new information and constructs that were not captured in the previous face-to-face interviews are also assessed (e.g., self-regulation, religion, life events, and life transitions). Due to the cross-sequential design, and given the planned total duration of 8 years of assessments, TwinLife will cover an age range from 5 years of age (youngest cohort at measurement point 1) to an age of 31 (oldest cohort at the last measurement). Altogether, five face-to-face interviews in the participants' homes and four telephone interviews in the years in between are envisaged. Thus, our measurement starts before children enter primary school and ends when most young adults have decided on their career.

Important transitions with a key function for developmental pathways (e.g., from pre-school to school and from primary school to secondary school) tend to occur between the first and second measurement occasions. The sample size of 1,000 same-sex twin pairs in each cohort provides increased statistical power for implementing $\mathrm{G} \times \mathrm{E}$ and $\mathrm{rGE}$ in our analyses (see Narusyte et al., 2008; Purcell, 2002).

In the further course of the study, we will define several criteria following the twin families throughout the study. Although this will increase the complexity of our data structure, divorce and separation of parents as well as one or more persons moving into the twins' household constitute important experiences and will therefore be captured in our study. Biological parents and biological (half-) siblings who leave the original household will also be followed and further assessed. We intend to follow non-biological parents or siblings only if they stay in close contact with the twins, because members of these groups can only exert an environmental influence on the twins. For economic reasons, data from persons not living in the twins' household was and will be collected by mail, telephone, or through online assessment whenever possible at the same measurement times planned for persons living in the twins' household, thus, not hampering the quality of the data.

\section{Extended Twin Family Design}

The original NTFD was applied in a modified form as the focus not only lies on the twins and their biological relatives, but also on the family in which the twins were raised, thus, also including step-family members and the twins' partners. If it was the case that the twins grew up in a step-family or some kind of blended family, data collection also comprised step-family members (e.g., stepfather or half-sibling) when they were living in the same household as the twins. In these cases, the biological parents living outside the household were also asked to participate in the study. In this way, we ensure covering environmental as well as genetic influences passed on from parents to their children. We also included half-, step-, and adoptive-siblings, but given the restriction of only one additional sibling per twin pair, the sibling with the highest degree of genetic relatedness and the smallest age difference to the twins was preferred. Furthermore, when the twins have reached a certain age (cohort 4), partners or spouses are included in the measurement because they may represent an important aspect of the environment. In addition, their inclusion sheds light on the sources of spouse similarity (e.g., phenotypic assortment and social homogamy) and its contribution to individual differences and thus to social inequality (e.g., Kandler et al., 2012).

This ETFD offers several advantages over the classical twin design (CTD; e.g., Eaves, 2009) since the CTD is based on some restrictive assumptions that are not always met for a phenotype under study (e.g., negligible non-additive genetic effects or the absence of assortative mating). Although the CTD provides reasonably accurate estimates of broad heritability (Coventry \& Keller, 2005; Hahn et al., 2012), extended designs can provide estimates of non-additive effects in the presence of environmental effects shared within families such as vertical transmission (i.e., non-genetic factors shared by parents and offspring) or sibling effects (i.e., non-genetic factors shared between siblings and twins but not between parents and offspring). They consider assortative mating and social background factors shared by siblings, parents, and spouses of twins. They also allow for more specific analyses of environmental effects shared by family members, such as twin-specific, sibling-specific, and spouse-specific shared influences (Keller et al., 2009).

\section{Representative Sample}

One of the primary tasks for the first wave of TwinLife was the assurance of a sample that proportionally reflects key characteristics of families in all four cohorts. To establish a representative (twin family) sample on the one hand, and to cover a large range of behavior and environments on the other hand, we implemented a sophisticated sampling procedure that includes a proportional 'basic sample' as well as additional samples of large municipalities (50,000 or more inhabitants) and rural regions (5,000 to under 20,000 inhabitants). Given that a central twin register is not available in Germany, twins were identified through local registration offices. Identified twin families were first contacted via mail and informed about the study. Within a couple of 
TABLE 2

Overview of the Net Sample of the First Half of TwinLife

\begin{tabular}{lrrrrr}
\hline & Cohort 1 & Cohort 2 & Cohort 3 & Cohort 4 & Total \\
\hline Twins & 1,008 & 1,024 & 1,048 & 938 & 4,018 \\
Mother & 493 & 493 & 484 & 436 & 1,906 \\
Stepmother & 0 & 2 & 6 & 3 & 11 \\
Father & 347 & 335 & 304 & 224 & 1,210 \\
Stepfather & 11 & 19 & 32 & 16 & 78 \\
Siblings & 204 & 278 & 206 & 130 & 818 \\
Twins' partners & - & - & - & 75 & 75 \\
Total & 2,063 & 2,151 & 2,080 & 1,822 & 8,116 \\
Families & 504 & 512 & 524 & 469 & 2,009 \\
Households & 508 & 521 & 549 & 844 & 2,422 \\
Participation rate & $46 \%$ & $45 \%$ & $47 \%$ & $23 \%$ & $37 \%$ \\
Family complete & $77 \%$ & $78 \%$ & $74 \%$ & $58 \%$ & $72 \%$ \\
Family incomplete & $23 \%$ & $22 \%$ & $26 \%$ & $42 \%$ & $28 \%$ \\
\hline
\end{tabular}

days after this first contact, trained interviewers visited the families at home to establish personal contact to the families, provide further information about TwinLife, and ask whether the families were interested in participating. The main focus of our strategy was to realize an unbiased sample with respect to the twins' families SES and the twins' sex. As we are also interested in economic information of non-responders in comparison to responders, we asked for assumed zygosity, number of siblings, sex, and SES at the initial contact at home.

\section{Sample Description}

The first wave of TwinLife was organized in two 'half waves'. By the end of 2015, the first half of the sample had completed the first in-house, face-to-face interview. In total, 2,009 twin families comprising 8,116 individuals living in 2,422 households were interviewed. Twin families were drawn from German communities of at least 5,000 inhabitants across all federal states. Participation of twin families consisting of at least both twins and one biological parent differed between cohorts: In the youngest three cohorts 45$47 \%$ of the gross sample (a random sample drawn from resident registers) agreed to participate. In the oldest age cohort, this was achieved in $23 \%$ of the gross sample of twin families.

One reason for the lower participation rate of this cohort is that in these families the respondents required to establish a valid case often live in different households and are therefore not as easily accessible as families in the younger birth cohorts. However, an overall response rate of $37 \%$ could be considered as satisfactory and comparable to other German twin studies (Spinath \& Wolf, 2006). A participation rate of this level is generally not achieved in Germany during general population surveys and thus represents a good result, especially in the light of the extensive volume of the interviews. Besides the twins, especially their biological mothers showed a high willingness to participate in the survey (97\%, biological fathers: $77 \%$ ). In families with a sibling at survey age ( 5 years and older), this sibling participated in $93 \%$ of the cases. In $72 \%$ of the surveyed families, a complete case including the biological parents and, if present, the stepparent, sibling, and partners of the twins could be realized. With respect to the following telephone interview within the longitudinal design, the willingness to be interviewed again was exceptionally high (about 95\%), which provides the basis for a stable twin family panel. For more details on the structure of the sample, see Table 2.

In the first half of the sample that has been collected so far, about $45 \%$ (approx. 900 cases) of the same-sex twin pairs are male and 55\% (approx. 1,100 cases) are female. Zygosity of the twin pairs was balanced across all cohorts, with $46 \%$ monozygotic (MZ) and 54\% dizygotic twin (DZ) pairs. In detail, the sample included $216 \mathrm{MZ}$ pairs (43\%) in the youngest cohort, $204(40 \%)$ in the second cohort, 254 (48\%) in the third, and $255 \mathrm{MZ}$ pairs (53\%) in the oldest cohort. The sample represents the whole range of typically investigated socio-economic backgrounds. Hence, the sample facilitates socio-structural differentiated genotype sensitive analyses.

In the first half of the TwinLife data, we did not find the 'middle class bias' - overrepresentation of medium SES groups - often present in general population surveys. However, given the current sample, families with lower occupational status and no or lower secondary education are slightly under-represented compared to the socio-economic structure of similar twin and non-twin families in the German population. To further improve data quality and to reach a more accurate representation of each occupational status for the full sample of the first wave of face-to-face interviews, additional recruitment strategies with respect to families with lower socioeconomic background were set for the second half of the sample.

\section{Future Directions}

The main task for the following periods will be to establish more waves of data collection and to realize a longitudinal design covering longer trajectories and more than one life 
period linked by various types of transitions. In addition to this task, we plan to include molecular genetic data into our analyses. DNA samples will not be collected before the third measurement occasion for two reasons: first, we wanted to minimize panel attrition in the critical early stages, as it was demonstrated in pre-test studies of other surveys that almost $20 \%$ of panel participants adamantly refuse to provide saliva. We expected that the increased level of trust between interviewer and interviewee after having participated in the study for some time will increase the participation rate.

Second, since molecular genetics is a rapidly evolving field, we expect the emergence of both improved statistical procedures and more closely spaced genetic markers, as well as an improved understanding of the genetic and evolutionary mechanisms involved in the heritability of complex traits (e.g., concerning gene expression and epigenetics) over the next 5 years.

A satellite project, 'Early Childhood Education and Care Quality and Child Development: an Extension Study of Twins', was first launched to seize the opportunity that for the youngest cohort, independent information about day-care centers as an important part of the environment could be collected. This project is a co-operation of Martin Diewald, Katharina Spieß, and Pia Schober, funded by the Jacobs Foundation. Parents of the youngest cohort were asked to give the interviewer the name and address of the day-care centers of the twins. The respective center will now be contacted, and both the manager of the day-care institution and the kindergarten worker directly responsible for the twins' group will be interviewed about quality measures, structural conditions, and specific measures in the day-care center. Other satellite projects could focus on rather extensive studies on biological mechanisms linking the genome to social behaviors and outcomes, and use a sub-sample of TwinLife for this. Studies investigating genetic and biological mechanisms in great detail but with a small and nonrandom sample could use TwinLife as a reference study to check in which respects respondents differ from a representative sample.

\section{Acknowledgments}

This research was supported by a grant from the German Research Foundation awarded to Martin Diewald (DI 759/11-1), Rainer Riemann (RI 595/8-1), and Frank M. Spinath (SP 610/6-1). The authors declared no potential conflicts of interest with respect to the research, authorship, and publication of this article.

\section{References}

Abbott, A. (2001). Time matters: On theory and method. Chicago: University of Chicago Press.

Abendroth, A., Melzer, S. M., Jacobebbinghaus, P., \& Schlechter, F. (2014). Methodenbericht Beschäftigten- und
Partnerbefragung des Linked-Employer-Employee Panels (LEEP-B3) im Projekt B3 'Wechselwirkungen zwischen Verwirklichungschancen im Berufs- und Privatleben'(SFB 882 Technical Report Series, 6). Bielefeld: DFG Research Center. Retrieved from http://pub.uni-bielefeld.de/ publication/2700763.

Alkire, S. (2005). Subjective quantitative studies of human agency. Social Indicators Research, 74, 217-260.

Becker, A., Busjahn, A., Faulhaber, H., Bähring, S., Robertson, J., Schuster, H., \& Luft, F. (1997). Twin zygosity. Automated determination with microsatellites. Journal of Reproductive Medicine, 42, 260-266.

Beierlein, C., Kovaleva, A., Kemper, C. J., \& Rammstedt, B. (2012). Ein Messinstrument zur Erfassung subjektiver Kompetenzerwartungen: Allgemeine Selbstwirksamkeit Kurzskala (ASKU) (GESIS Working Papers 2012). Köln: GESIS. Retrieved from http://nbn-resolving.de/urn:nbn: de:0168-ssoar-292351.

Blossfeld, H.-P., von Maurice, J., \& Schneider, T. (2011). Grundidee, Konzeption und Design des Nationalen Bildungspanels für Deutschland, NEPS Working Paper, 1. Retrieved from http://www.uni-bamberg.de/fileadmin/inbil/ Publikationen/Working-Papers/WP_I.pdf.

Boer, F., Westenberg, P. M., McHale, S. M., Updegraff, K. A., \& Stocker, C. M. (1997). The factorial structure of the Sibling Relationship Inventory (SRI) in American and Dutch samples. Journal of Social and Personal Relationships, 14, 851859.

Bonanno, G. A. (2004). Loss, trauma, and human resilience: Have we underestimated the human capacity to thrive after extremely aversive events?. The American Psychologist, 59, 20-28.

Breen, R., \& Jonsson, J. O. (2005). Inequality of opportunity in comparative perspective: Recent research on educational attainment and social mobility. Annual Review of Sociology, 31, 223-243.

Breen, R., Luijkx, R., Müller, W., \& Pollak, R. (2009). Nonpersistent inequality in educational attainment: Evidence from eight European countries. American Journal of Sociology, 114, 1475-1521.

Breslau, J., Michael, L., Nancy, S. B., \& Kessler, R. C. (2008). Mental disorders and subsequent educational attainment in a US national sample. Journal of Psychiatric Research, 42, 708-716.

Byrd, A. L., \& Manuck, S. B. (2014). MAOA, childhood maltreatment, and antisocial behavior: Meta-analysis of a gene-environment interaction. Biological Psychiatry, 75, 9-17.

Caspi, A., McClay, J., Moffitt, T. E., Mill, J., Martin, J., Craig, I. W., ... Poulton, R. (2002). Role of genotype in the cycle of violence in maltreated children. Science, 297, 851-854.

Conley, D., Domingue, B., Cesarini, D., Dawes, C., Rietveld, C., \& Boardman, J. (2015). Is the effect of parental education on offspring biased or moderated by genotype?. Sociological Science, 2, 82-105.

Costa, P. T., \& McCrae, R. R. (1992). Four ways five factors are basic. Personality and Individual Differences, 13, 653665. 
Coventry, W. L., \& Keller, M. C. (2005). Estimating the extent of parameter bias in the classical twin design: A comparison of parameter estimates from extended twin-family and classical twin designs. Twin Research and Human Genetics, 8, 214-223.

Cunha, F., \& Heckman, J. J. (2009). The economics and psychology of inequality and human development. Journal of the European Economic Association, 7, 320-364.

Dickhäuser, O., Schöne, C., Spinath, B., \& Stiensmeier-Pelster, J. (2002). Die Skalen zum akademischen Selbstkonzept. Zeitschrift Für Differentielle Und Diagnostische Psychologie, 23, 393-405.

Diener, E., Emmons, R. A., Larsen, R. J., \& Griffin, S. (1985). The satisfaction with life scale. Journal of Personality Assessment, 49, 71-75.

Duckworth, A. L., \& Quinn, P. D. (2009). Development and validation of the short grit scale (Grit-S). Journal of Personality Assessment, 91, 166-174.

Eaves, L. (2009). Putting the 'human' back in genetics: Modeling the extended kinships of twins. Twin Research and $\mathrm{Hu}$ man Genetics, 12, 1-7.

Ellert, U., Lampert, T., \& Ravens-Sieberer, U. (2005). Messung der gesundheitsbezogenen Lebensqualität mit dem SF-8. Bundesgesundheitsblatt-GesundheitsforschungGesundheitsschutz, 48, 1330-1337.

Erikson, R., \& Goldthorpe, J. H. (1992). The constant flux: A study of class mobility in industrial societies. Oxford: Oxford University Press.

Esch, P., Bocquet, V., Pull, C., Couffignal, S., Lehnert, T., Graas, M., ... Ansseau, M. (2014). The downward spiral of mental disorders and educational attainment: A systematic review on early school leaving. BMC Psychiatry, 14, 237.

Farber, S. L. (1981). Identical twins reared apart: A reanalysis. New York: Basic Books.

Fowler, J. H., \& Schreiber, D. (2008). Biology, politics, and the emerging science of human nature. Science, 322, 912-914.

Freese, J. (2008). Genetics and the social science explanation of individual outcomes. American Journal of Sociology, 114, S1-S35.

Frey, A., Althaus, D., \& Duhm, E. (2008). Beobachtungsbogen für 3-bis 6-jährige Kinder: BBK 3-6; Manual. Göttingen: Hogrefe.

Gadermann, A. M., Schonert-Reichl, K. A., \& Zumbo, B. D. (2010). Investigating validity evidence of the satisfaction with life scale adapted for children. Social Indicators Research, 96, 229-247.

Gerlitz, J.-Y., \& Schupp, J. (2005). Zur Erhebung der Big-Fivebasierten Persönlichkeitsmerkmale im SOEP. Dokumentation der Instrumentenentwicklung BFI-S auf Basis des SOEP-Pretests 2005, DIW Research Notes, 4.

Giovannini, E., Hall, J., Morrone, A., \& Ranuzzi, G. (2011). A framework to measure the progress of societies. Revue D'économie Politique, 121, 93-118.

Gjone, H., \& Nøvik, T. S. (1995). Parental ratings of behaviour problems: A twin and general population comparison. Jour- nal of Child Psychology and Psychiatry, and Allied Disciplines, 36, 1213-1224.

Goldthorpe, J. H. (2010). Analysing social inequality: A critique of two recent contributions from economics and epidemiology. European Sociological Review, 26, 731-744.

Goodman, R. (1997). The strengths and difficulties questionnaire: A research note. Journal of Child Psychology and Psychiatry, 38, 581-586.

Grusky, D. B., Ku, M. C., \& Szeleńyi, S. (2008). Social stratification: Class, race, and gender in sociological perspective. Boulder, CO: Westview.

Guo, G., \& Stearns, E. (2002). The social influences on the realization of genetic potential for intellectual development. Social Forces, 80, 881-910.

Hahn, E., Gottschling, J., \& Spinath, F. M. (2013). Current twin studies in Germany: Report on CoSMoS, SOEP, and ChronoS. Twin Research and Human Genetics, 16, 173-178.

Hahn, E., Specht, J., Gottschling, J., \& Spinath, F. M. (2015). Coping with unemployment: The impact of unemployment duration and personality on trajectories of life satisfaction. European Journal of Personality, 29, 635-646.

Hahn, E., Spinath, F. M., Siedler, T., Wagner, G. G., Schupp, J., \& Kandler, C. (2012). The complexity of personality: Advantages of a genetically sensitive multi-group design. Behavior Genetics, 42, 221-233.

Hauser, R. M., Warren, J. R., Huang, M.-H., \& Carter, W. Y. (2000). Occupational status, education, and social mobility in the meritocracy. In K. Arrow, S. Bowles, \& S. Durlauf (Eds.), Meritocracy and economic inequality (pp. 179-229). Princeton, NJ: Princeton University Press.

Headey, B. (2010). The set point theory of well-being has serious flaws: On the eve of a scientific revolution?. Social Indicators Research, 97, 7-21.

Heath, A. C., Kendler, K. S., Eaves, L. J., \& Markell, D. (1985). The resolution of cultural and biological inheritance: Informativeness of different relationships. Behavior Genetics, 15, 439-465.

Heckman, J. J. (2006). Skill formation and economics of investing in disadvantaged children. Science, 312, 1900-1902.

Heckman, J. J., \& Kautz, T. (2012). Hard evidence on soft skills. Labour Economics, 19, 451-464.

Heyeres, U. (2006). Adult sibling relationship questionnaire. Gruppendynamik und Organisationsberatung, 37, 215-225.

Huinink, J., Brüderl, J., Nauck, B., Walper, S., Castiglioni, L., \& Feldhaus, M. (2011). Panel analysis of intimate relationships and family dynamics (pairfam): Conceptual framework and design. Zeitschrift für Familienforschung [Journal of Family Research], 23, 77-101.

Ivcevic, Z., \& Brackett, M. (2014). Predicting school success: Comparing conscientiousness, grit, and emotion regulation ability. Journal of Research in Personality, 52, 29-36.

Jackson, M., Goldthorpe, J. H., \& Mills, C. (2005). Education, employers and class mobility. Research in Social Stratification and Mobility, 23, 3-33. 
Jencks, C., \& Tach, L. (2006). Would equal opportunity mean more mobility?. In S. Morgan, D. Grusky, \& G. Fields (Eds.), Mobility and inequality: Frontiers of research in sociology and economics (pp. 23-58). Stanford, CA: Stanford University Press.

Kandler, C., Bleidorn, W., \& Riemann, R. (2012). Left or right? sources of political orientation: The roles of genetic factors, cultural transmission, assortative mating, and personality. Journal of Personality and Social Psychology, 102, 633-645.

Keller, M. C., Medland, S. E., Duncan, L. E., Hatemi, P. K., Neale, M. C., Maes, H. H. M., \& Eaves, L. J. (2009). Modeling extended twin family data I: Description of the cascade model. Twin Research and Human Genetics, 12, 8-18.

Kendler, K. S. (2001). Twin studies of psychiatric illness: An update. Archives of General Psychiatry, 58, 1005-1014.

Kerbo, H. (2011). Social stratification and inequality (8th ed.). New York, NY: McGraw-Hill Education.

Kuhn, J.-T., Holling, H., \& Freund, P. A. (2008). Begabungsdiagnostik mit dem Grundintelligenztest (CFT 20-R). Psychometrische Eigenschaften und Messäquivalenz. Diagnostica, 54, 184-192.

Lareau, A. (2002). Invisible inequality: Social class and childrearing in black families and white families. American Sociological Review, 67, 747-776.

Lucas, R. E. (2007). Adaptation and the set-point model of subjective well-being: Does happiness change after major life events?. Current Directions in Psychological Science, 16, 75-79.

Marsh, H. W., Ellis, L. A., \& Craven, R. G. (2002). How do preschool children feel about themselves? Unraveling measurement and multidimensional self-concept structure. Developmental Psychology, 38, 376-393.

McAuley, E., Duncan, T., \& Tammen, V. V. (1989). Psychometric properties of the intrinsic motivation inventory in a competitive sport setting: A confirmatory factor analysis. Research Quarterly for Exercise and Sport, 60, 48-58.

Narusyte, J., Neiderhiser, J. M., D’Onofrio, B. M., Reiss, D., Spotts, E. L., Ganiban, J., \& Lichtenstein, P. (2008). Testing different types of genotype-environment correlation: An extended children-of-twins model. Developmental Psychology, 44, 1591-1603.

Oishi, S., Kesebir, S., \& Diener, E. (2011). Income inequality and happiness. Psychological Science, 22, 1095-1100.

Oniszczenko, W., Angleitner, A., Strelau, J., \& Angert, T. (1993). The Questionnaire of Twins' Physical Resemblance, University of Warsaw, Poland, and University of Bielefeld, Germany. Unpublished manuscript.

Pinker, S. (2003). The blank slate: The modern denial of human nature. New York: Penguin Books.

Plomin, R., \& Crabbe, J. (2000). DNA. Psychological Bulletin, 126, 806-828.

Plomin, R., DeFries, J. C., McClearn, G. E., \& McGuffin, P. (2008). Behavioral genetics (5th ed.). New York: Worth Publishers.

Polderman, T. J. C., Benyamin, B., De Leeuw, C. A., Sullivan, P. F., Van Bochoven, A., Visscher, P. M., \& Posthuma, D. (2015). Meta-analysis of the heritability of human traits based on fifty years of twin studies. Nature Genetics, 47, 702-709.

Poropat, A. E. (2009). A meta-analysis of the five-factor model of personality and academic performance. Psychological Bulletin, 135, 322-338

Price, T. S., Freeman, B., Craig, I., Petrill, S. A., Ebersole, L., \& Plomin, R. (2000). Infant zygosity can be assigned by parental report questionnaire data. Twin Research and $\mathrm{Hu}$ man Genetics, 3, 129-133.

Purcell, S. (2002). Variance components models for geneenvironment interaction in twin analysis. Twin Research and Human Genetics, 5, 554-571.

Reinecke, J., Stemmler, M., Sünkel, Z., Schepers, D., Weiss, M., Arnis, M., ... Wittenberg, J. (2013). The development of deviant and delinquent behavior over the life course in the context of processes of social inequalities (SFB 882 Working Paper Series, 17). Bielefeld: DFG Research Center. Retrieved from http://pub.uni-bielefeld.de/publication/2563479.

Richardson, M., Abraham, C., \& Bond, R. (2012). Psychological correlates of university students' academic performance: A systematic review and meta-analysis. Psychological Bulletin, 138, 353-387. 6838

Robins, R. W., Hendin, H. M., \& Trzesniewski, K. H. (2001). Measuring global self-esteem: Construct validation of a single-item measure and the Rosenberg self-esteem scale. Personality and Social Psychology Bulletin, 27, 151-161.

Rosenberg, M. (1965). Society and the adolescent self-image. Princeton, NJ: Princeton University Press.

Roth, B., Hahn, E., \& Spinath, F. M. (2016). Income inequality, life satisfaction, and economic worries. Social Psychological and Personality Science. Advance online publication.

Rowe, D. C., Jacobson, K. C., \& Van den Oord, E. J. (1999). Genetic and environmental influences on vocabulary IQ: Parental education level as moderator. Child Development, 70, 1151-1162.

Runciman, W. G. (1972). Relative deprivation and social justice: A study of attitudes to social inequality in twentieth century England. Harmondsworth, UK: Penguin Books.

Rutter, M., Pickles, A., Murray, R., \& Eaves, L. (2001). Testing hypotheses on specific environmental causal effects on behavior. Psychological Bulletin, 127, 291-324.

Scarr, S. (1992). Developmental theories for the 1990s: Development and individual differences. Child Development, 63, $1-19$.

Scarr, S. (1993). Biological and cultural diversity: The legacy of Darwin for development. Child Development, 64, 13331353.

Scarr-Salapatek, S. (1971). Race, social class, and IQ. Science, 174, 1285-1295.

Shanahan, M. J., Hofer, S. M., \& Shanahan, L. (2003). Biological models of behavior and the life course. In J. T. Mortimer, \& M. J. Shanahan (Eds.), Handbook of the life course (pp. 597-622). Boston: Springer.

Shavit, Y., \& Blossfeld, H.-P. (Eds.). (1993). Persistent inequality: Changing educational attainment in thirteen countries (Social Inequality Series). Boulder, CO: Westview Press. 
Smeeding, T., Erikson, R., \& Jäntti, M. (2011). Introduction. In T. Smeeding, R. Erikson, \& M. Jäntti (Eds.), Persistence, privilege, and parenting (pp. 1-26). New York: Russell Sage Foundation.

Spinath, B., Stiensmeier-Pelster, J., Schöne, C., \& Dickhäuser, O. (2002). Skalen zur Erfassung der Lern-und Leistungsmotivation (SELLMO). Göttingen: Hogrefe.

Spinath, F. M., \& Wolf, H. (2006). CoSMoS and TwinPaW: Initial Report on two new German twin studies. Twin Research and Human Genetics, 9, 787-790.

Steinmayr, R., \& Spinath, B. (2010). Konstruktion und erste Validierung einer Skala zur Erfassung subjektiver schulischer Werte (SESSW). Diagnostica, 56, 195-211.

Stiglitz, J. E., Sen, A., Fitoussi, J.-P. (Eds.). (2010). Report by the commission on the measurement of economic performance and social progress. Paris: Commission on the Measurement of Economic Performance and Social Progress. Retrieved from http://www.stiglitz-sen-fitoussi. fr/en/documents.html.

Tucker-Drob, E. M., \& Bates, T. C. (2016). Large crossnational differences in gene $\times$ socioeconomic status interaction on intelligence. Psychological Science, 27, 138149.

Tucker-Drob, E. M., Rhemtulla, M., Harden, K. P., Turkheimer, E., \& Fask, D. (2011). Emergence of a gene $\times$ socioeconomic status interaction on infant mental ability between 10 months and 2 years. Psychological Science, 22, 125-133.

Turkheimer, E. (2000). Three laws of behavior genetics and what they mean. Current Directions in Psychological Science, 9, 160-164.

Turkheimer, E., Haley, A., Waldron, M., d'Onofrio, B., \& Gottesman, I. I. (2003). Socioeconomic status modifies heritability of IQ in young children. Psychological Science, 14, 623-628.

Visscher, P. M., Brown, M. A., McCarthy, M. I., \& Jang, J. (2012). Five years of GWAS discovery. American Journal of Human Genetics, 90, 7-24.

Wagner, G. G., Frick, J. R., \& Schupp, J. (2007). The German socio-economic panel study (SOEP): Evolution, scope and enhancements (SOEP papers on Multidisciplinary Panel Data Research 1, DIW). Berlin: The German Socio-Economic Panel (SOEP).

Wang, Z., Deater-Deckard, K., Petrill, S. A., \& Thompson, L. A. (2012). Externalizing problems, attention regulation, and household chaos: A longitudinal behavioral genetic study. Development and Psychopathology, 24, 755-769.

Warwick-Booth, L. (2013). Social inequality: A student's guide. London: Sage Publications.

Weiß, R. H., \& Osterland, J. (2013). Grundintelligenztest Skala 1 -Revision: CFT 1-R. Göttingen: Hogrefe.

Welsch, H. (2007). Macroeconomics and life satisfaction: Revisiting the ;misery index. Journal of Applied Economics, 10, 237-251. 